\title{
Gastrointestinal responses of turkeys to the addition of exogenous xylanase and glucanase to diets
}

\author{
J. Juśkiewicz ${ }^{1,3}$, D. Mikulski ${ }^{2}$, J. Jankowski ${ }^{2}$ and Z. Zduńczyk ${ }^{1}$ \\ ${ }^{1}$ Institute of Animal Reproduction and Food Research, Polish Academy of Sciences \\ Tuwima 10, 10-747 Olsztyn, Poland \\ ${ }^{2}$ Warmia and Mazury University in Olsztyn, Department of Poultry Science \\ Oczapowskiego 2, 10-957 Olsztyn, Poland
}

\begin{abstract}
Changes in digesta parameters were examined in turkeys fed for 8 weeks on diets with and without the addition of an enzymatic preparation, Kemzyme ${ }^{\circledR W}$ Liquid, in doses of 50, 100 and 150 $\mathrm{mg} / \mathrm{kg}$. The preparation contained a specified mixture of xylanase and glucanases. The diet with the highest addition of exogenous enzymes decreased ileal viscosity (1.21 vs $1.33 \mathrm{mPa}$ s $)$ and weight of ileal tissue (10.6 vs $13.4 \mathrm{~g} / \mathrm{kg} \mathrm{BW}$ ) compared with the control group. Dietary enzymes did not influence either hydration or $\mathrm{pH}$ of caecal digesta, but decreased the activity of bacterial enzymes as well and tended to increase short-chain fatty acid contents in the caeca. The highest dietary addition of an enzymatic preparation decreased caecal viscosity (3.04 $\mathrm{mPa} * \mathrm{~s})$ compared with the control (3.79 $\mathrm{mPa} \cdot \mathrm{s})$ and other experimental groups (3.50-3.51 $\left.\mathrm{mPa}{ }^{\circ}\right)$.
\end{abstract}

KEY WORDS: non-starch polysaccharides, microbial enzymes, xylanase, caecal fermentation, turkey

\section{INTRODUCTION}

Non-starch polysaccharides (NSP), the main ingredients of the endosperm of cereals, are generally undigested in the upper part of the gastrointestinal tract of poultry but can be hydrolysed to a small extent by caecal microflora. It was shown that the addition of xylanase (Choct et al., 1999) or a complex of enzymes (Józefiak et al., 2004), improved the digestibility of NSP of wheat- and barley-based diets in chickens. The aim of the study was to investigate the enzymes added (three doses of a $\beta$-xylanase and $\beta$-glucanase mixture) to wheat and barley-based diets in turkeys.

\footnotetext{
${ }^{3}$ Corresponding author: e-mail: glebczo@pan.olsztyn.pl
} 


\section{MATERIAL AND METHODS}

A total of 420 BIG-6 female turkeys divided into four groups (four replications with 21 birds each) were fed a control diet containing $10 \%$ barley and 37 or $40 \%$ wheat in the period of 1-4 and 5-8 weeks, respectively. Experimental diets were supplemented with the Kemzyme ${ }^{\circledR W}$ Liquid preparation (Kemin Industries, Inc.) at doses of: 50,100 and $150 \mathrm{mg} / \mathrm{kg}$ (group $\mathrm{K}_{50}, \mathrm{~K}_{100}$ and $\mathrm{K}_{150}$, respectively). The preparation contained 1,4- $\beta$-xylanase $(210000 \mathrm{U} / \mathrm{g}), 1,3(4)-\beta$-glucanase $(10000$ $\mathrm{U} / \mathrm{g}), 1,4-\beta$-glucanase $(120000 \mathrm{U} / \mathrm{g})$, and $\alpha$-amylase (400 U/g). After 8 weeks of feeding, 8 turkeys from each group were killed, the small intestine and caeca with contents were removed and emptied. The $\mathrm{pH}$ of the ileal and caecal digesta was measured using a microelectrode and pH/ION meter (model 301, Hanna Instruments). Empty ileum and caeca were flushed clean, blotted and weighed. Samples of fresh caecal digesta were used for determining dry matter, microbial enzyme activity and short-chain fatty acid (SCFA) concentrations.

The viscosity of intestinal and caecal digesta was determined using a Brookfield cone-plate viscometer Model LVDV-II (Brookfield Engineering Laboratories Inc., Stoughton, MA). Samples of ileal and caecal digesta were diluted with water at a 1:1 or 1:2 ratio, respectively. The caecal digesta was analysed for VFA concentration by gas chromatography (Shimadzu GC-14A with a glass column $2.5 \mathrm{~m} \times 2.6$ $\mathrm{mm}$, containing $10 \% \mathrm{SP}-1200 / 1 \% \mathrm{H}_{3} \mathrm{PO}_{4}$ on $80 / 100$ Chromosorb W AW, column temperature $110^{\circ} \mathrm{C}$, detector FID temperature $180^{\circ} \mathrm{C}$, injector temperature $195^{\circ} \mathrm{C}$ ). Microbial enzyme activity in the caecal digesta was measured by the rate of $\mathrm{p}$ - or o-nitrophenol release from their nitrophenylglucosides according to the modified method of Djouzi and Andrieux described by Juśkiewicz et al. (2002). The results were analysed using one-way ANOVA and the Duncan's multiple range test.

\section{RESULTS}

As shown in Table 1, the supplementation of diets with carbohydrases significantly decreased the viscosity of intestinal digesta and mass of ileal wall. The $\mathrm{pH}$ of intestinal and caecal digesta was also numerically lowered. Supplementation of the diet with the enzyme preparation had no significant effect on the mass of empty caeca, DM content and $\mathrm{pH}$ of digesta. A lower activity of microbial enzymes was found in turkeys fed diets with the addition of the enzymatic preparation. The content of acetic acid in the caecal digesta of group $\mathrm{K}_{100}$ was higher, while the content of propionic acid in groups $\mathrm{K}_{100}$ and $\mathrm{K}_{150}$ was lower than in the control group. Due to a larger amount of caecal digesta, the SCFA pool was numerically the highest in group $\mathrm{K}_{150}$.

The acetic acid content in the caecal digesta of group $\mathrm{K}_{100}$ was significantly higher than in the control and $\mathrm{K}_{150}$ groups, the latter with the highest addition 
of enzymes. Experimental groups were characterized by a higher propionic acid content compared with the control. Due to a larger amount of caecal digesta, the total ceacal SCFA production (SCFA pool) appeared to be the highest in group $\mathrm{K}_{150}$ turkeys.

Table 1. The effect of enzyme addition on ileal and caecal parameters of turkeys

\begin{tabular}{|c|c|c|c|c|c|}
\hline & Control & $\mathrm{K}_{50}$ & $\mathrm{~K}_{100}$ & $\mathrm{~K}_{150}$ & SEM \\
\hline Ileal viscosity, $\mathrm{mPa} \bullet \mathrm{s}$ & $1.33^{\mathrm{a}}$ & $1.29^{\mathrm{ab}}$ & $1.27^{\mathrm{ab}}$ & $1.21^{\mathrm{b}}$ & 0.02 \\
\hline $\mathrm{pH}$ of ileal digesta & 6.04 & 5.78 & 5.61 & 5.62 & 0.08 \\
\hline Intestinal wall, $\mathrm{g} / \mathrm{kg} \mathrm{BW}$ & $13.4^{\mathrm{a}}$ & $11.6^{\mathrm{ab}}$ & $11.7^{\mathrm{ab}}$ & $10.6^{\mathrm{b}}$ & 0.17 \\
\hline Caecal wall, g/kg BW & 3.59 & 3.45 & 3.50 & 3.67 & 0.07 \\
\hline Caecal digesta, $\mathrm{g} / \mathrm{kg} \mathrm{BW}$ & 3.60 & 3.97 & 3.80 & 4.17 & 0.22 \\
\hline Dry matter of caecal digesta, $\%$ & 16.9 & 16.3 & 16.2 & 16.3 & 0.33 \\
\hline $\mathrm{pH}$ of caecal digesta & 5.47 & 5.69 & 5.61 & 5.74 & 0.05 \\
\hline Viscosity of caecal digesta, mPa.s & $3.79^{\mathrm{a}}$ & $3.50^{\mathrm{a}}$ & $3.51^{\mathrm{a}}$ & $3.04^{\mathrm{b}}$ & 0.15 \\
\hline$\alpha$-glucosidase, $\mathrm{U} / \mathrm{g}$ digesta & $1.98^{\mathrm{a}}$ & $1.25^{\mathrm{b}}$ & $1.88^{\mathrm{ab}}$ & $1.86^{\mathrm{ab}}$ & 0.12 \\
\hline$\beta$-glucosidase, $\mathrm{U} / \mathrm{g}$ digesta & $0.66^{\mathrm{ab}}$ & $0.48^{\mathrm{b}}$ & $0.92^{\mathrm{a}}$ & $0.79^{\mathrm{ab}}$ & 0.06 \\
\hline$\alpha$-galactosidase, $\mathrm{U} / \mathrm{g}$ digesta & 3.54 & 3.08 & 2.38 & 2.13 & 0.24 \\
\hline$\beta$-galactosidase, $\mathrm{U} / \mathrm{g}$ digesta & $6.87^{\mathrm{a}}$ & $5.29^{\mathrm{ab}}$ & $2.79^{\mathrm{b}}$ & $3.68^{\mathrm{b}}$ & 0.48 \\
\hline$\beta$-glucuronidase, $\mathrm{U} / \mathrm{g}$ digesta & $2.90^{\mathrm{a}}$ & $1.45^{\mathrm{b}}$ & $1.54^{\mathrm{b}}$ & $1.44^{\mathrm{b}}$ & 0.20 \\
\hline \multicolumn{6}{|l|}{ SCFA concentration, $\mu \mathrm{mol} / \mathrm{g}$} \\
\hline acetic & $48.1^{\mathrm{b}}$ & $51.4^{\mathrm{ab}}$ & $56.6^{\mathrm{a}}$ & $46.1^{\mathrm{ab}}$ & 1.50 \\
\hline propionic & $28.1^{\mathrm{a}}$ & $22.4^{\mathrm{ab}}$ & $21.2^{\mathrm{b}}$ & $19.1^{\mathrm{b}}$ & 1.16 \\
\hline isobutyric & 0.65 & 1.07 & 0.85 & 1.08 & 0.10 \\
\hline butyric & 17.8 & 17.5 & 19.8 & 17.5 & 0.60 \\
\hline isovaleric & 0.79 & 1.03 & 0.98 & 1.01 & 0.06 \\
\hline valeric & 2.21 & 2.29 & 2.32 & 2.11 & 0.08 \\
\hline total & 97.7 & 95.7 & 102 & 86.9 & 2.46 \\
\hline \multicolumn{6}{|l|}{ SCFA pool, $\mu \mathrm{mol} / \mathrm{kg} B W$} \\
\hline acetic & 178 & 204 & 215 & 210 & 13.37 \\
\hline propionic & 106 & 89.2 & 80.6 & 83.9 & 6.92 \\
\hline total & 363 & 379 & 386 & 393 & 24.2 \\
\hline
\end{tabular}

a,b different superscripts within a row indicate significant differences, $\mathrm{P}<0.05$

\section{DISCUSSION}

Supplementation of diets with exogenous enzymes, especially at a high dose of $150 \mathrm{mg} / \mathrm{t}$, lowered intestinal viscosity. This is consistent with the results obtained by Choct et al. (1999) and Józefiak et al. (2004). The lower activity of microbial enzymes observed in the present study may indicate that enzymatic preparations decreased the amount of easily fermentable carbohydrates in caecal digesta. This refers to the soluble fraction of NSP (i.e. soluble arabinoxylans and/or $\beta$-glucans), 
which plays an important role in the formation of viscosity in ileal digesta (Lázaro et al., 2003). The addition of exogenous enzymes increased the concentration of SCFA, mainly of acetic acid, in caecal digesta. In the experiment of Józefiak et al. (2004), the increase in SCFA concentration was more distinct: almost two times higher in broilers fed barley- or oat-diets supplemented with xylanase and protease. In other studies, enzymatic preparations added to rye diets did not increase the SCFA concentration in caecal digesta (Lázaro et al., 2003).

\section{CONCLUSIONS}

Supplementing diets with a mixture of exogenous xylanase and $\beta$-glucanase lowered the viscosity in intestinal and caecal digesta, the activity of bacterial enzymes and enhanced the production of some SCFA. This effect points to a change of bacterial populations in the caeca; it was more distinct at the highest dose of the enzymatic preparation administered to the diet.

\section{REFERENCES}

Choct M., Hughes R.J., Bedford M.R., 1999. Effect of a xylanase on individual bird variation, starch digestion throughout the intestine, and ileal and caecal volatile fatty acid production in chickens fed wheat. Brit. Poultry Sci. 40, 419-422

Józefiak D., Rutkowski A., Frątczak M., Boros D., 2004. The effect of dietary fibre fractions from different cereal and microbial enzymes supplementation on performance, ileal viscosity and short-chain fatty acid concentrations in the caeca of broiler chickens. J. Anim. Feed Sci. 13, 487-496

Juśkiewicz J., Zduńczyk Z., Wróblewska M., Oszmiański J., Hernandez T., 2002. The response of rats to feeding with diets containing grapefruit flavonoid extract. Food Res. Int. 35, 201-205

Lázaro R., Garcia M., Medel P., Mateos G.G., 2003. Influence of enzymes on performance and digestive parameters of broilers fed rye-based diets. Poultry Sci. 82, 132-140

\section{STRESZCZENIE}

Reakcja przewodu pokarmowego indyków na zawartość w mieszance ezgogennej ksylanazy i glukanazy

Analizowano zmiany w składzie i właściwościach treści pokarmowej indyków żywionych przez 8 tygodni mieszankami bez lub z dodatkiem 50,100 lub $150 \mathrm{mg} / \mathrm{kg}$ preparatu enzymatycznego zawierającego mieszaninę ksylanazy oraz glukanaz. Największy dodatek enzymów obniżył lepkość treści (1,21 vs $1,33 \mathrm{mPa} \cdot \mathrm{s})$ i masę tkanki jelita cienkiego (10,6 vs $13,4 \mathrm{~g} / \mathrm{kg}$ m.c.) w porównaniu z grupą kontrolną. Dodatek enzymów nie wpłynął na uwodnienie i pH treści jelita ślepego, natomiast obniżył aktywność enzymów glikolitycznych mikroflory jelitowej; stwierdzono też tendencję zwiększenia produkcji lotnych kwasów thuszczowych. Największy dodatek preparatu do diety obniżył lepkość treści jelit ślepych $(3,04 \mathrm{mPa} \cdot \mathrm{s})$ w porównaniu z grupą kontrolną $(3,79 \mathrm{mPa} \cdot \mathrm{s}) \mathrm{i}$ pozostałymi grupami doświadczalnym $(3,50-3,51 \mathrm{mPa} \cdot \mathrm{s})$. 